\title{
Sport related injuries attending the accident and emergency department
}

\author{
Richard Spencer Jones FRCS and Thomas Taggart MB ChB \\ Orthopaedic Department, Walton Hospital, Liverpool, UK
}

\begin{abstract}
Of new patients attending our hospital, $7.1 \%$ had injured themselves playing sport. The majority had been playing football and had sustained a soft tissue injury. Many of the patients presented late, i.e. after $24 \mathrm{~h}$ or longer. These patients would be best dealt with in a sports clinic, staffed by personnel with an interest in this field.
\end{abstract}

Keywords: Sporting injuries

With the rise in unemployment and the reduction in working hours, the average person has more free time to devote to recreational activities. The increasing numbers of people attending accident and emergency ( $A$ and $E$ ) departments with sport related injuries adds to the work load of the casualty staff. However, not all who have been injured in sport attend an A and E department, as first aid at the scene plays an important part in the management of these injuries ${ }^{1}$. In this study, we have attempted to quantify the numbers of patients with sporting injuries attending the casualty department in our hospital and we make some suggestions for dealing with this problem.

\section{Method}

Walton Hospital is one of three large general hospitals and one children's hospital serving the city of Liverpool with accident and emergency facilities. Its catchment population is 320000 people and there are numerous sports clubs in the surrounding area. The A and E Department sees 91000 new patients each year. The surrounding area is one of high unemployment.

All new patients seen in the A and E Department over a 10-day period in October 1992 were questioned about their reason for attending. Those that had sport related injuries were then asked to complete a questionnaire, giving details of the sport they were participating in at the time of the injury, how often they play that sport and to what level. Details of their injuries and treatment were also recorded.

Address for correspondence: Mr Richard Spencer Jones FRCS, Maywood, Grove Road, Mollington, Chester CH1 6LG, UK

(C) 1994 Butterworth-Heinemann Ltd 0306-3674/94/020110-02

\section{Results}

During the period of study, 2432 new patients were seen in the A and E Department, $1280(52.6 \%)$ were classed as trauma patients and $172(7.1 \%)$ were sport related. Their mean age was 22 years (range 8-60 years) and the majority of these patients were male $(82 \%)$. Of the patients $33(19.2 \%)$ worked in sedentary jobs, $31(18.0 \%)$ were manual workers, 70 $(40.7 \%)$ were school children or students, and 38 (22.1\%) were unemployed. The sport being played at the time of injury is shown in Table 1, the frequency the patient played the sport in Table 2 and to what standard in Table 3.

Ninety five patients were seen on a weekday and 77 at the weekend. After the accident 100 patients (58.1\%) came to the A and E Department that same

Table 1. The distribution of injuries according to sport played

\begin{tabular}{lc}
\hline Sport & $\begin{array}{c}\text { No. of patients } \\
n=172\end{array}$ \\
\hline Football & 112 \\
Basketball/netball/volleyball & 19 \\
Weight training & 8 \\
Hockey/lacrosse & 6 \\
Boxing/karate/wrestling & 5 \\
Jogging & 4 \\
Dancing & 2 \\
Gymnastics & 2 \\
Motorcycle racing & 2 \\
Roller skating & 2 \\
Rugby & 2 \\
Swimming & 2 \\
Tennis & 2 \\
Aerobics & 1 \\
Diving & 1 \\
Horse riding & 1 \\
Skiing & 1 \\
\hline
\end{tabular}

Table 2. The frequency of sport participation by patients

\begin{tabular}{lc}
\hline Frequency & $\begin{array}{c}\text { No. of patients } \\
n=172\end{array}$ \\
\hline Everyday & 17 \\
Twice or three times per week & 77 \\
Once a week & 58 \\
Once a month & 6 \\
Occasionally & 14 \\
\hline
\end{tabular}


Table 3. The level at which the patients played their sport

\begin{tabular}{lc}
\hline Level & $\begin{array}{c}\text { No. of patients } \\
n=172\end{array}$ \\
\hline Professional & 2 \\
Club level/amateur & 63 \\
For fun/to keep fit & 93 \\
Novice/beginner & 14 \\
\hline
\end{tabular}

Table 4. Nature of injuries of trauma patients attending $A$ and $E$ Department

\begin{tabular}{lcc}
\hline Type of injury & $\begin{array}{c}\text { Sport related } \\
n=172\end{array}$ & $\begin{array}{c}\text { Nonsport related } \\
n=1108\end{array}$ \\
\hline Head injury & 6 & 196 \\
Eye injury & 2 & 10 \\
Laceration & 7 & 227 \\
Dislocation of joint & 5 & 12 \\
Fracture & 30 & 120 \\
Soft tissue injury & 122 & 543 \\
\hline
\end{tabular}

day, $40(23.3 \%)$ came within $24 \mathrm{~h}$ and $32(18.6 \%)$ took longer to present. Of the patients $43(25.0 \%)$ had had a similar injury in the past. Six patients $(3.5 \%)$ had been told to give up this sport in the past for medical reasons, and $5(2.9 \%)$ were planning to give up their sport as a result of their current injury. Insurance policies were held by 17 patients $(9.9 \%)$ to cover them against sport related injuries.

Table 4 shows the nature of the injuries in sport and nonsport trauma patients attending the $\mathrm{A}$ and $\mathrm{E}$ Department in the 10-day study period. The majority of these injuries were to the extremities $(32.6 \%$ arm and $55.2 \%$ leg), $1.7 \%$ chest, $9.3 \%$ to head or face, and $1.2 \%$ spine. Follow up was required by 52 patients $(30.2 \%)$ in either a redressing or orthopaedic clinic. Six patients $(3.5 \%)$ required admission to hospital for treatment or observation.

It can be seen from Table 1 that the majority of patients in this study had been playing football $(65.1 \%)$. Of this group, $89.3 \%$ played at least once a week and $41.1 \%$ considered themselves to be of professional or amateur/club standard.

\section{Discussion}

The proportion of new patients attending the $\mathrm{A}$ and $\mathrm{E}$ Department at our hospital with sports injuries $(7.1 \%)$ was greater than the number reported in other series $^{2,3}$. However DeHaven and Lintner ${ }^{4}$, in reporting the injuries attending the University of Rochester Section of Sports Medicine over a 7-year period, showed that males accounted for $80.3 \%$ of these sporting injuries with an average patient age of 21.6 years. Our smaller study produced similar figures (mean age 22 years, $82 \%$ males).

Despite there being a large children's hospital with $A$ and $E$ facilities within 2 miles of our hospital, a large proportion of those attending were children under the age of 16 years $(27.9 \%)$. This implies that the casualty is still taken to the nearest hospital, rather than the specialist centre.

The distribution of injuries is similar to those reported by DeHaven and Lintner ${ }^{4}$, the lower limb, and in particular the knee, being the most frequently injured part. This was to be expected, as a large proportion of those injured $(65.1 \%)$ were playing football with its associated high incidence of leg injuries ${ }^{5}$. Surprisingly there were no fractures of the tibia or fibula requiring internal fixation during the study period. In previous weeks, there had been an average one or two such fractures per week needing operative treatment.

Our study period spanned two weekends on the assumption that most sport was played on Saturdays and Sundays, and therefore most sport related casualties would present at this time. Despite the acute nature of their accident, almost half the soft tissue injuries $(47.5 \%)$ and slightly fewer patients with fractures $(39.3 \%)$ presented $24 \mathrm{~h}$ or more after their injury. The A and E Department was attended by 32 patients $(18.6 \%)$ on the only Monday in the study period.

The large numbers of sport related trauma patients presenting to the $\mathrm{A}$ and $\mathrm{E}$ Department $24 \mathrm{~h}$ or more after injury with mainly soft tissue injuries, suggests the need for a sports injury clinic, with medical and physiotherapy facilities, to deal with these minor injuries. These patients are young, and usually previously healthy. Their injuries may result in time off work and subsequent loss of earnings. We therefore recommend that such a clinic would be available on at least a Monday, be well advertised at local sporting facilities, and be staffed by personnel interested in this aspect of healthcare.

\section{References}

1 Walkden L. Immediate management of injuries. Br J Sports Med 1981; 11: 68-70.

2 Pickard MA, Tullett WM, Patel AR. Sports injuries as seen at an accident and emergency department. Scott Med J 1988; 33: 296-7.

3 de Loes M. Medical treatment and costs of sports-related injuries in a total population. Int J Sports Med 1990; 11: 66-72.

4 DeHaven KE, Lintner DM. Athletic injuries: comparison by age, sport, and gender. Am J Sports Med 1986; 14: 218-24.

5 Schmidt-Olsen S, Jorgensen U, Kaalund S, Sorensen J. Injuries among young soccer players. Am J Sports Med 1991; 19: 273-5. 